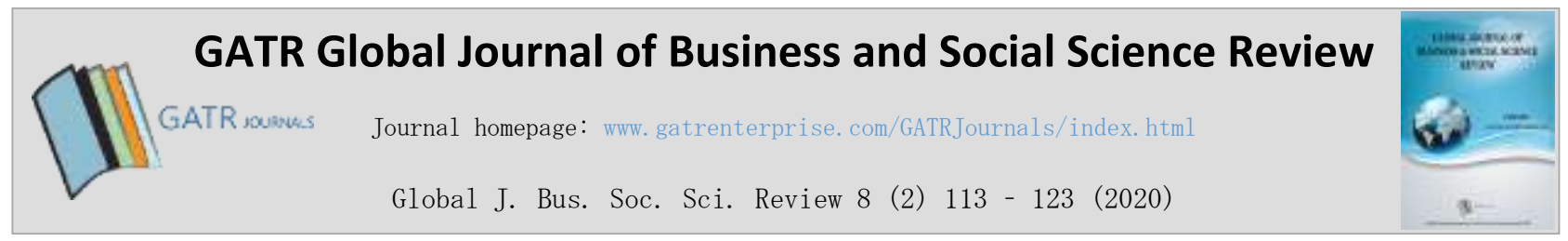

\title{
Instructional Leadership Capacity of Elementary School Administrators
}

\author{
Runato A. Basañes, PhD \\ University of Antique 5713 Sibalom, Antique, Philippines
}

\begin{abstract}
Objective - The purpose of this study is to determine the level of instructional leadership among public elementary school administrators in Antique, Philippines.

Methodology/Technique - The study was conducted using the descriptive survey design to a sample of 182 purposively selected public elementary school administrators in the School Division of Antique, Philippines. The researcher adapted the National Competency-Based Standards for School Heads Questionnaire for this study. The questionnaire was originally constructed by the Department of Education (DepEd) - National Educators Academy of the Philippines (DepEd - NEAP).

Finding - The results reveal that public elementary school administrators have poor knowledge in instructional leadership, specifically in developing programs and or adapting existing programs. The results also show that the public elementary school administrators have moderate knowledge in Assessment of Learning, Implementing Programs for Instructional Improvement, and Instructional Supervision.

Novelty - The study suggests instructional leadership training programs for school administrators to increase their competence in instructional leadership so they can achieve the goals of their respective schools.
\end{abstract}

Type of Paper: Empirical.

JEL Classification: A21, I23.

Keywords: Assessment of Learning; Capability Enhancement Program; Instructional Leadership Capacity; Instructional Supervision; School Programs Development; School Program Implementation.

Reference to this paper should be made as follows: Basañes, R.A. (2020). Instructional Leadership Capacity of Elementary School Administrators, Global J. Bus. Soc. Sci. Review, 8(2): $113-123$. https://doi.org/10.35609/gjbssr.2020.8.2(5)

\section{Introduction}

With the demands of globalization in today's world, education systems need to be transformed to meet the needs of students. The education system needs to be designed taking into consideration the demands of the 21 st century and future generations. Rapid development and technological advancement have made most advanced countries in the world to re-evaluate their education systems (Bakar, 2013).

\footnotetext{
* Paper Info: Revised: March 10, 2020

Accepted: June 3, 2020

* Corresponding author: Runato A. Basañes,

E-mail: runatob@yahoo.com

Affiliation: University of Antique, Philippines
} 
Nonetheless, implementing of these new initiatives will not materialize if the school leaders who are the change agents are incompetent and cannot handle the programs effectively. Experienced school leaders should cooperate with the government in achieving the agenda of the nation's educational growth. On the other hand, incompetent school leaders in leadership perform poorly in the process of educational transformation (Yusri, 2012). This makes quality instructional leadership essential to educational transformation. The effectiveness of education is a product of Good School Leadership Practices. These practices contribute greatly to the transformational process of every educational institution.

Several researches attest to this. The essence of Instructional Leadership Principles in managing change has been highlighted by some recent researchers (Sim, 2011; Kin, 2013; Bibi, 2012; Hazura, 2009). As a result, instructional leaders are considered as the key contributors to the success in the implementation of change in schools (Leithwood \& Day, 2008; Sahin, 2011). Because of this, in every educational transformation, the practice of instructional leadership is always highlighted. Wahyuni, Putrawan and Sari (2019) report that empowering educational institutions is extremely important, especially in countries where education is lagging behind. This means that the role of effective instructional leadership is critical. In relation to this, Mulyasa (2012) states that school principals play a large role in coordinating and harmonizing educational resources in schools. Principals are therefore mandated to have competent management and leadership skills in order to lead educational institutions.

The present Philippine educational system is being decentralized. Authority for making decisions for school improvement has devolved to the school level and therefore calls for school principals to be accountable for the quality of education provided in their schools. School principals play a vital role in a decentralized education system, more specifically on the capacity for instructional leadership of public administrators (Governance of Basic Education Act of 2001, Republic Act 9155).

The researcher (a former Education Program Supervisor) observed that there is a need to improve the educational management outcomes among school administrators in the division with the focus on school administrators' leadership capacity and instructional leadership support. This will help them to realize the vision, mission, goals, and objectives of the Department of Education (DepEd). DepEd has already invested a significant amount in providing Technical Assistance for public elementary school administrators with the School-Based Management (SBM) at the frontline, and there is the need to look into the factors that contribute to their effective instructional leadership capacity so as to improve school quality under the decentralized system. This would strengthen management at the school level and help in providing teachers incentives to motivate and improve teaching practice.

\subsection{Theoretical Background}

Kursunoglu and Tanriogen (2009) explain instructional leadership as a series of behaviors that affect classroom instruction. The theory of instructional leadership has been widely studied (Hallinger \& Walker, 2017; Montecinos et. al., 2018; Akiba, 2017), and there are various models and theories that explain instructional leadership. Some of these models and theories include that of Hallinger and Murphy Models (1985), Model Weber (1996), Model Jensen and Murphy (1990) and Mc Ewan Model (2009). Hallinger and Murphy (1985) explain instructional leadership as principals' behaviors that promote and improve the process of teaching and learning in schools. This theory involves teachers, students, parents, school planning, school management, school facilities and resources. Most researchers (Jamelaa, \& Jainabee, 2011; Premavathy, 2010; Sukarmin, 2010; Wan Roslina, 2011; Brown \& Chai, 2012; Lyons, 2010; Mattar, 2012) on instructional leadership anchored their studies on the model of Hallinger and Murphy (1985).

The Hallinger and Murphy (1985) Model presents 3 dimensions in instructional leadership activities. The dimensions are:

1) determining school mission;

2) managing instructional programs; and

Global J. Bus. Soc. Sci. Review 8 (2) $113-123$ (2020) 
3) creating school learning environment.

The instructional leadership in this model includes 11 leadership components:

1) drawing on school goals;

2) explaining school goals;

3) supervising and evaluating teaching;

4) coordinating curriculum;

5) monitoring students' progress;

6) assuring instructional time;

7) maintaining learning support;

8) providing incentives for teachers;

9) enforcing academic standards;

10) promoting professional development; and

11) providing incentives for learning.

Philip Hallinger built the Principal Instructional Management Rating Scale (PIMRS) of this model. This instrument has been used in more than 175 surveys worldwide (Hallinger, 2015). The concept of instructional leadership is related to the needs and requirements of policy, research and management, and practice of school leadership. This makes it necessary to look into the factors that contribute to effective instructional leadership capacity of principals within a decentralized system.

\subsection{Literature Review}

Instructional leadership is generally defined as the management of curriculum and instruction by a school principal (Horn \& Little, 2017). A study on effective school movement in the United States revealed that a principal's role is key to effective instructional leadership (Printy, Marks \& Bowers, 2009). Moreover, a principal is vital in ensuring success in learning with children in poor urban elementary schools, and therefore they must be mindful, sincere, and charismatic (Hallinger, 2003, 2009).

Instructional leadership that focuses on the principal's role was strong during the 1990s. However, when it drew criticisms, scholars explored other models such as transformational leadership, teacher leadership, shared leadership, and distributed leadership (Spillane, Halverson \& Diamond, 2001; Hallinger, 2009; Halverson, Grigg, Prichett \& Thomas, 2007).

\subsubsection{Instructional Leadership Approaches}

Instructional leadership is either exclusive or inclusive (Robinson, Lloyd \& Rowe, 2008). In Exclusive Instructional Leadership, the principal is the main authority in setting goals for the school, supervision and instruction (Hallinger, 2015). On the other hand, Inclusive Instructional Leadership includes other school staff in addition to the principal. According to Marks and Printy (2003), an inclusive approach to instructional leadership is a shared leadership where principals collaborate with teachers in developing curriculum and instruction to improve the academic performance of pupils. In addition, Hallinger (2003) suggests the integration of transformational leadership with instructional leadership wherein staff are empowered in their role and are encouraged to support the principal.

Southworth (2002) further explains that instructional leadership involves both direct and indirect activities. The direct activities are considered a narrow mode of instructional leadership with immediate actions related to instruction, such as classroom observation and curriculum development as the focus. On the other hand, the indirect activities are a broad mode of instructional leadership which broadly focuses on creating the school climate, as well as direct activities. 


\subsubsection{Instructional Leadership and School Excellence}

It is reported by Lee, Hallinger and Walker (2012) that policymakers and policy practitioners consider instructional leadership as a key factor in effective schools. This is because the concept of instructional leadership according to Hallinger (2003) and Hallinger and Leithwood (1994) is based on effective school research, implementation of change and school improvement. In this regard, the practice is emphasized by the Ministry of Education (MOE) as a means of ensuring excellence in schools. The Malaysian Quality Standards introduced by the Inspectorate and Quality Assurance stipulate that principals in Malaysian schools serve as instructional leaders. Principals lead the implementation of the curriculum and create a learning environment that encourages the adoption of a learning culture among students (Butler et. al., 2015). Hoy and Hoy (2003) emphasise the importance of instructional leadership by stating that the main function of the school is the teaching and learning process. Therefore, as instructional leaders, principals need to prioritize improving the quality of teaching and learning as the main focus of the school.

The quality of teaching has an important correlation with the level of instructional leadership practices in a school. Several studies on the relationship between instructional leadership and teaching quality have identified a significant correlation between the 2 (Zahara \& Suria, 2011; Sazali, Rusmini, Hut \& Zamri, 2007). Yusri and Aziz (2014) reveal that instructional leadership has a positive relationship and contributes significantly to teachers' teaching competence. This is also supported by the study of Rahimi and Yusri (2015). According to the researchers, instructional leadership of principals contributes significantly to the teaching competence of teachers. Since teachers are the main facilitators of teaching and learning in the classroom, the quality of teaching can affect the learning output of students (Hallinger, 2011).

Research by Abdullah, Ali, Mydin, and Amin (2019), Zahara and Suria (2011) and Quah (2011) also confirms that instructional leadership practices contribute to the quality of students' learning outcomes and has a stronger influence on student learning than transformational leadership (Abdullah, Ling \& Sufi, 2018). This means that instructional leadership is a major factor for achieving school goals and improving students' learning outcomes.

\subsubsection{Instructional Leadership and Managing Change}

Changes in educational policies and systems aim at improving the quality of existing education systems. The outcome therefore is to provide higher quality human capital in the nation (Santhidran, Chandran, \& Borromeo, 2013). In this regard, schools should be dynamic and undergo evolution in this era of globalization. This means principals must embrace change in terms of values, practices, attitude and thoughts (Hou, Cui \& Zhang, 2019). As good as this may sound, this is not always straightfoward. Most educators find it very difficult to embrace change. This much is confirmed by several researchers (Hallinger, 2009; Fullan, 2007). Thus, school leaders must endeavor to embrace change in implementing new educational policies in order to achieve learning outcomes (Khan \& Malik, 2013; Jamelaa, 2012; Helterbran, 2010); Fullan, 2007). Several other researchers state that school leaders who practice instructional leadership find it easier to implement changes in education in Malaysia (Nor Azni, 2015; Bond, 2015; Rahimi, 2014; Yusri, 2012; Jameela, 2012; Hattie, 2015).

A willingness to change is the first change phase based on the Model of Kurt Lewin (1951). It should be addressed to ensure that resistance to change is minimized in school leaders. School principals will fail in their attempts to manage change effectively if the members of the organization are not ready to change even in the first stage of implementation (Urick \& Bowers 2014). A study by Jamelaa (2012) reveals that there is a significant correlation between instructional leadership and the attitude of the principals on change. Emphatically, when the leaders of instruction display a positive attitude towards change, teachers support and are ready to implement the change (Nor Azni, 2015). However, competence on the part of the principals is very crucial. They must possess the skills and knowledge to implement change (Suseela \& Sim, 2010). 


\section{Research Methodology}

This study was conducted using a descriptive survey method. The study involved 182 Public Elementary School Administrators (PESA) in the School Division of Antique, Philippines from 2018-2019. The study adapted a questionnaire from the National Competency-Based Standards for School Heads (NCBSSH) of the Department of Education (DepEd) - National Educators Academy of the Philippines (NEAP) (DO No. 32, 2010).

The questionnaire consisted of 4 competency strands. Each strand had statements that focused on the competencies of the school administrators. The strands were:

1) Assessment of Learning;

2) Developing Programs and or Adopting Existing Programs;

3) Implementing Programs for Instructional Improvement; and

4) Instructional Supervision.

The scores of individual respondents in the Instructional Leadership Capacity Questionnaire were determined by adding the numerical equivalents of the options chosen and then means were computed. The weight and their corresponding response categories were adapted from DO No. 32 series of 2010. The data was analyzed using frequency, percentage, standard deviation, and mean. All statistical computations were processed through SPSS software, Version 22.0 (Hair, Black, Babin \& Anderson, 2010).

\section{Results and Discussions}

\subsection{Overall Level of Instructional Leadership Capacity (ILC)}

Table 1 below shows the Overall Level of Instructional Leadership Capacity among the public-school administrators. The ILC for the entire administrators was high with a mean score of 2.78 , and a standard deviation of 0.40 . This means that the school principals are moderately competent in instructional leadership. The results also portray limitations in the administrators' ability to manage and implement programs in their schools. The overall mean for developing programs and/or adopting existing programs was 2.35 with a standard deviation of 0.36 . The descriptive equivalence was low. This indicates that the administrators have a poor know-how in developing programs and/or adopting existing programs. These findings could be due to the lower amount of instructional leadership training available for principals, and their incompetence in the conduct of the research (Hallinger, 2013).

Table 1. Overall Level of Instructional Leadership Capacity

\begin{tabular}{ccccc}
\hline & Instructional leadership & Mean & SD & Description \\
\hline $\mathbf{A}$ & Assessment of learning & $\mathbf{3 . 0 5}$ & $\mathbf{0 . 4 9}$ & High \\
1 & Manage the processes and procedures in monitoring student achievement. & 3.11 & 0.57 & High \\
2 & Ensure utilization of a range of assessment processes to assess student \\
performance. & 3.06 & 0.53 & High \\
& $\quad$ & & & \\
3 & Assess the effectiveness of curricular/co-curricular programs and/or & 3.13 & 0.49 & High \\
& instructional strategies. & & & \\
4 & Utilize assessment results to improve learning. & 3.10 & 0.53 & High \\
5 & Create \& manage a school process to ensure student progress is conveyed to & 2.85 & 0.73 & High \\
& students and parents/guardians, regularly. & & & \\
B & Developing programs and or adopting existing programs & $\mathbf{2 . 3 5}$ & $\mathbf{0 . 3 6}$ & Low \\
1 & Develop/adapt a research-based school program. & 2.13 & 0.55 & Low \\
\hline
\end{tabular}




\begin{tabular}{|c|c|c|c|c|}
\hline 2 & $\begin{array}{l}\text { Assist in implementing an existing, coherent and responsive school-wide } \\
\text { curriculum. }\end{array}$ & 2.36 & 0.51 & Low \\
\hline 3 & $\begin{array}{l}\text { Address deficiencies and sustain successes of current programs in } \\
\text { collaboration with teachers, and learners. }\end{array}$ & 2.43 & 0.53 & Low \\
\hline 4 & Develop a culture of functional literacy. & 2.46 & 0.44 & Low \\
\hline $\mathbf{C}$ & Implementing programs for instructional improvement & 2.57 & 0.50 & High \\
\hline \multirow[t]{2}{*}{1} & Manage the introduction of curriculum initiatives in line with DepEd policies & & & \\
\hline & & 2.65 & 0.45 & High \\
\hline 2 & Work with teachers in curriculum review. & 2.55 & 0.54 & High \\
\hline 3 & Enrich curricular offerings based on local needs. & 2.52 & 0.58 & High \\
\hline 4 & Manage curriculum innovation and enrichment with the use of technology. & 2.58 & 0.52 & High \\
\hline \multirow[t]{2}{*}{5} & Organize teams to champion instructional innovation programs toward & & & \\
\hline & curricular responsiveness. & 2.54 & 0.53 & High \\
\hline D & Instructional supervision & 3.15 & 0.55 & High \\
\hline 1 & Prepare and implement an instructional supervisory plan. & 3.18 & 0.62 & High \\
\hline 2 & Conduct Instructional Supervision using appropriate strategy. & 3.14 & 0.64 & High \\
\hline 3 & Evaluate lesson plans as well as classroom and learning management. & 3.21 & 0.65 & High \\
\hline 4 & Provide in a collegial manner timely, accurate and specific feedback to & & & \\
\hline \multirow{3}{*}{5} & teachers' regarding their performance. & 3.10 & 0.62 & High \\
\hline & Provide expert technical assistance and instructional support to teachers. & 3.12 & 0.69 & High \\
\hline & Over-all Mean & 2.78 & 0.40 & High \\
\hline
\end{tabular}

\subsection{Level of Instructional Leadership Capacity According to Age}

Table 2 displays the findings from the analysis based on age. It can be observed that strands A, C and D were high among the school administrators. It could be inferred that if the administrators are grouped by age, they are moderately competent in instructional leadership. On the other hand, their ability to develop programs and/or adopt existing programs was low, meaning that they have poor ability to develop programs and/or adopt existing programs. This could partly explain why most instructional leaders resist change in programs and systems in schools. Their know-how does not match the competence it takes to implement new programs and systems (Hoy, 2013).

Table 2. Level of Instructional Leadership Capacity According to Age

\begin{tabular}{|c|c|c|c|c|c|c|c|c|c|c|}
\hline & \multirow[b]{2}{*}{ Instructional leadership } & \multicolumn{3}{|c|}{$32-41$ years old } & \multicolumn{3}{|c|}{$42-51$ years old } & \multicolumn{3}{|c|}{$52-62$ years old } \\
\hline & & Mean & SD & Desc. & Mean & SD & Desc. & Mean & SD & Desc. \\
\hline A & Assessment of learning & 3.06 & 0.57 & High & 3.02 & 0.44 & High & 3.02 & 0.48 & High \\
\hline B & $\begin{array}{l}\text { Developing programs and or } \\
\text { adopting existing programs }\end{array}$ & 2.50 & 0.39 & Low & 2.41 & 0.34 & Low & 2.44 & 0.37 & Low \\
\hline $\mathrm{C}$ & $\begin{array}{l}\text { Implementing programs for } \\
\text { instructional improvement }\end{array}$ & 2.55 & 0.18 & High & 2.53 & 0.20 & High & 2.54 & 0.20 & High \\
\hline $\mathrm{D}$ & Instructional Supervision & 3.21 & 0.69 & High & 3.17 & 0.49 & High & 3.08 & 0.60 & High \\
\hline
\end{tabular}

\subsection{Level of Instructional Leadership Capacity according to Length of Administrative Experience}

Table 3 below presents the results on the level of instructional leadership capacity of the school administrators according to their length of experience. For strands A, C and D, the principals' level of competence was rated as high with means of 3.03, 2.51 and 3.16 respectively, and a standard deviation of $0.42,0.16$ and 0.40 respectively. It can therefore be inferred that the principals are moderately competent with regards to strands A, C and D. It could also be said that length of experience does not have any significant influence on their level of competence in instructional leadership. Interestingly, irrespective of 
length of experience, all the administrators' level of competence did significantly differ. Conversely, their level of competence in the implementation of programs and/or adapting existing programs was rated as low. It could be explained that the administrators, irrespective of their age, have poor know-how in developing programs and or adapting existing programs (Carrier, 2011).

Table 3. Level of Instructional Leadership Capacity according to Length of Administrative Experience

\begin{tabular}{lcccccccccc}
\hline & & \multicolumn{3}{c}{$1-9$ years } & \multicolumn{3}{c}{$10-19$ years } & \multicolumn{3}{c}{ 20-30 years } \\
& Instructional leadership & Mean & SD & Desc. & Mean & SD & Desc. & Mean & SD & Desc. \\
\hline A & Assessment of learning & 3.05 & 0.46 & High & 3.04 & 0.48 & High & 3.03 & 0.42 & High \\
B & $\begin{array}{c}\text { Developing programs and or } \\
\text { adopting existing programs }\end{array}$ & 2.41 & 0.33 & Low & 2.49 & 0.33 & Low & 2.50 & 0.30 & Low \\
& C Implementing programs for & & & & & & & & & \\
& instructional improvement & 2.51 & 0.20 & High & 2.53 & 0.20 & High & 2.51 & 0.16 & High \\
D & Instructional Supervision & 3.12 & 0.53 & High & 3.15 & 0.59 & High & 3.16 & 0.40 & High \\
\hline
\end{tabular}

\subsection{Level of Instructional Leadership Capacity according to position}

The results in Table 4 below reveal that the administrators have high Instructional Leadership Capacity across the 3 competency strands of instructional leadership namely: assessment of learning, implementing programs for instructional improvement, and instructional supervision. This demonstrates that the positions of the administrators had no significant influence on their competency in instructional leadership. It could be said that they are moderately competent in the 3 strands mentioned above. Further examination of the table however reveals that regardless of their position, the respondents have low ILC in implementing programs and/or adapting existing programs. This may imply that these administrators have poor knowledge on program implementation and therefore need training in relation to how to implement new programs and adapt existing programs (Boohene \& Williams, 2012).

Table 4. Level of Instructional Leadership Capacity According to Position

\begin{tabular}{lcccccccccc}
\hline & & \multicolumn{3}{c}{ Principal } & \multicolumn{4}{c}{ Head Teacher } & \multicolumn{3}{c}{ OIC/TIC } \\
& Instructional leadership & Mean & SD & Desc. & Mean & SD & Desc. & Mean & SD & Desc. \\
\hline A & $\begin{array}{c}\text { Assessment of learning } \\
3.07\end{array}$ & 0.47 & High & 3.02 & 0.43 & High & 2.94 & 0.57 & High \\
B & $\begin{array}{c}\text { Developing programs and or } \\
\text { adopting existing programs }\end{array}$ & 2.46 & 0.36 & Low & 2.43 & 0.35 & Low & 2.42 & 0.40 & Low \\
C & $\begin{array}{c}\text { Implementing programs for } \\
\text { instructional improvement }\end{array}$ & 2.53 & 0.18 & High & 2.52 & 0.19 & High & 2.52 & 0.30 & High \\
D & Instructional Supervision & 3.15 & 0.49 & High & 3.05 & 0.49 & High & 2.63 & 0.88 & High \\
\hline
\end{tabular}

\subsection{Level of Instructional Leadership Capacity According to Sex}

The results of the ILC for the respondents when grouped according sex is provided in Table 5. The results show that both male and female public elementary school administrators have high ILC in assessment of learning, implementing programs for instructional improvement and instructional supervision. Male administrators seemed to show more consistency with higher mean scores in all of the strands compared to their female counterparts. This may suggest that males might be more competent in instructional leadership than females. However, both male and female administrators had low ILC in strand B (developing programs and/or adopting existing programs). This may imply that the administrators are poor in stand B and therefore may need more training on program implementation and management (Lyons, 2010). 
Table 5. Level of Instructional Leadership Capacity According to Sex

\begin{tabular}{|c|c|c|c|c|c|c|c|}
\hline \multirow{2}{*}{\multicolumn{2}{|c|}{ Instructional leadership }} & \multicolumn{3}{|c|}{ Male } & \multicolumn{3}{|c|}{ Female } \\
\hline & & Mean & $\mathrm{SD}$ & Desc. & Mean & $\mathrm{SD}$ & Desc. \\
\hline A & Assessment of learning & 3.07 & 0.40 & High & 3.00 & 0.49 & High \\
\hline B & $\begin{array}{c}\text { Developing programs and or adopting } \\
\text { existing programs }\end{array}$ & 2.49 & 0.35 & Low & 2.43 & 0.36 & Low \\
\hline $\mathrm{C}$ & $\begin{array}{c}\text { Implementing programs for instructional } \\
\text { improvement }\end{array}$ & 2.54 & 0.15 & High & 2.52 & 0.21 & High \\
\hline $\mathrm{D}$ & Instructional supervision & 3.13 & 0.48 & High & 3.02 & 0.57 & High \\
\hline
\end{tabular}

\section{Conclusion and Recommendations}

Based on the findings, the following conclusions can be drawn:

1) Public elementary school administrators are poorly equipped with the knowledge and skills in performing their instructional leadership functions specifically in developing programs and/or adopting existing programs.

2) Public elementary school administrators are moderately competent in strands A, C, and D (assessment of learning, implementing programs for instructional improvement, and instructional supervision respectively).

It is therefore recommended that Instructional Leadership Capability Enhancement Training should be conducted among public elementary school administrators on program development and/or adapting existing programs. This training will equip the administrators to perform their duties well. DepEd officials may formulate a comprehensive development plan as a basis for capability enhancement programs to raise the level of instructional leadership of public elementary school administrators. Furthermore, they may implement measures to monitor and evaluate the school administrators so as to provide appropriate interventions in schools that need attention.

\section{Acknowledgments}

Words are not enough to express the researcher's grateful and heartfelt gratitude for the continuous support, patience, motivation, and immense knowledge of the following persons: Dr. Jelyn O. Alentajan, Dean of the College of Teacher Education; Dr. Laura G. Perales, Adviser; Dr. Celedonia R. Hilario, External Evaluator; Dr. Geoffrey P. Basilio, Chairman; Dr. Ma. Josephine M. Mercado, Member; Dr. Ezperanza F. Mission, Member; Dr. Jose Freddie F. Mocon, Schools Division Superintendent for approving the researcher's study leave for one year; Dr. Reynaldo G. Gico, Asst. Schools Division Superintendent, and Officer-In-Charge for the permit to conduct the research.

\section{References}

Abdullah, A. G. K., Ling, Y. L., \& Sufi, S. B. (2018). Principal transformational leadership and teachers' motivation. Asian Education Studies, 3(1), 36.DOI: https://doi.org/10.20849/aes.v3i1.316

Abdullah, A. G. K., Ali, A. J., Mydin, A., Aiza, N., \& Amin, Z. (2019). Exploring Capacity of Midde Managers as Instructional Leadership to Lead Transformations of Teaching and Learning in Malaysian High Performing Schools. International Journal of Academic Research in Business and Social Sciences, 9(3). 
http://hrmars.com/hrmars_papers/Exploring_Capacity_of_Midde_Managers_as_Instructional_Leadership_to_Lead_Tra nsformations_of_Teaching_and_Learning_in_Malaysian_High_Performing_Schools1.pdf

Abubakar, A. (2013). Role of social studies education in national development in Nigeria. Academic Journal of Interdisciplinary Studies, 2(6), 23. Doi:10.5901/ajis.2013.v2n6p23

Akiba, M. (2017). Editor's introduction: Understanding cross-national differences in globalized teacher reforms. https://doi.org/10.3102/0013189X17711908

Bond, N. (Ed.). (2014). The power of teacher leaders: Their roles, influence, and impact. Routledge. https://books.google.com.pk/books?hl=en\&lr=\&id=DSIWBAAAQBAJ\&oi=fnd\&pg=PP1\&dq=Bond,+N.+(Ed.).+(2015 ).+The+power+of+teacher+leaders:+Their+roles, +influence, + and+impact.+New+York,+NY:+Routledge.\&ots=B5v40_ reO0\&sig=mMdsYvXflD5_wL76rh2YAMg-Jf4\&redir_esc=y\#v=onepage\&q\&f=false

Boohene, R., \& Williams, A. A. (2012). Resistance to organisational change: A case study of Oti Yeboah Complex Limited. International Business and Management, 4(1), 135-145. DOI: 10.3968/j.ibm.1923842820120401.1040

Brown, G. T., \& Chai, C. (2012). Assessing instructional leadership: a longitudinal study of new principals. Journal of Educational Administration. https://www.emerald.com/insight/content/doi/10.1108/09578231211264676/full/html

Butler, D. L., Schnellert, L., \& MacNeil, K. (2015). Collaborative inquiry and distributed agency in educational change: A case study of a multi-level community of inquiry. Journal of educational change, 16(1), 1-26. https://link.springer.com/article/10.1007/s10833-014-9227-z

Carrier, L. L. (2011). What is instructional leadership and what does it look like in practice? A multi-case case study of elementary school principals who have led schools from being identified as underperforming to performing. University of Massachusetts Amherst. https://search.proquest.com/openview/e6832247863381d5fd0c19a5c768a97e/1?pqorigsite $=$ gscholar $\& \mathrm{cbl}=18750 \&$ diss $=\mathrm{y}$

Fullan, M. (2010). Motion leadership: The skinny on becoming change savvy. Corwin Press. https://books.google.com.pk/books?hl=en\&lr=\&id=cBIs00uF7GcC\&oi=fnd\&pg=PR1\&dq=Fullan,+M.+(2009).+Motio $\mathrm{n}+$ Leadership\&ots=8mjOcJ7QKY\&sig=CK93MYUZ97blMhOaGh3DMe7YOrc\&redir_esc $=\mathrm{y} \# \mathrm{v}=$ onepage \&q=Fullan $\%$ 2C\%20M.\%20(2009).\%20Motion\%20Leadership\&f=false

Galdames, S., Montecinos, C., Campos, F., Ahumada, L., \& Leiva, M. V. (2018). Novice principals in Chile mobilizing change for the first time: Challenges and opportunities associated with a school's readiness for change. Educational Management Administration \& Leadership, 46(2), 318-338. https://doi.org/10.1177/1741143217707520

Hair, J. F., Black, W. C., Babin, B. J., Anderson, R. E., \& Tatham, R. L. (1998). Multivariate data analysis (Vol. 5, No. 3, pp. 207-219). Upper Saddle River, No https://pdfs.semanticscholar.org/6885/bb9a29e8a5804a71bf5b6e813f2f966269bc.pdf

Hallinger, P. (2009). Leadership for the 21st century schools: From instructional leadership to leadership for learning. https://repository.eduhk.hk/en/publications/leadership-for-the-21st-century-schools-from-instructional-leader-3

Hallinger, P., \& Murphy, J. (1985). Assessing the instructional management behavior of principals. The elementary school journal, 86(2), 217-247. http://dx.doi.org/10.1086/461445

Hallinger, P., \& Leithwood, K. (1994). Introduction: Exploring the impact of principal leadership. School Effectiveness and School Improvement, 5(3), 206-217.

Hallinger, P., Wang, W. C., \& Chen, C. W. (2013). Assessing the measurement properties of the principal instructional management rating scale: A meta-analysis of reliability studies. Educational Administration Quarterly, 49(2), 272-309. https://doi.org/10.1177/0013161X12468149

Hallinger, P., \& Walker, A. (2017). Leading learning in Asia-emerging empirical insights from five societies. Journal of Educational Administration. https://doi.org/10.1108/JEA-02-2017-0015

Hallinger, P. (2015). The evolution of instructional leadership. In Assessing instructional leadership with the principal instructional management rating scale (pp. 1-23). Springer, Cham. https://link.springer.com/chapter/10.1007/978-3-31915533-3_1

Hallinger, P. (2015). The evolution of instructional leadership. In Assessing instructional leadership with the principal instructional management rating scale (pp. 1-23). Springer, Cham. https://link.springer.com/chapter/10.1007/978-3-31915533-3_1

Halverson, R., Grigg, J., Prichett, R., \& Thomas, C. (2007). The new instructional leadership: Creating data-driven instructional systems in school. Journal of School Leadership, 17(2), 159-194.10.1177/105268460701700202.

Hattie, J. (2015). High-Impact Leadership. Educational leadership, 72(5), 36-40. https://eric.ed.gov/?id=EJ1051701

Mahat, H., \& Idrus, S. (2017). Education for sustainable development in Malaysia: A study of teacher and student awareness. Geografia-Malaysian Journal of Society and Space, 12(6). http://ejournal.ukm.my/gmjss/article/view/18022 
Horn, I. S., \& Little, J. W. (2010). Attending to problems of practice: Routines and resources for professional learning in teachers' workplace interactions. American educational research journal, 47(1), 181-217. https://doi.org/10.3102/0002831209345158

Hou, Y., Cui, Y., \& Zhang, D. (2019). Impact of instructional leadership on high school student academic achievement in China. Asia Pacific education Review, 20(4), 543-558.https://doi.org/10.1007/s12564-019-09574-4

Hoy, A. W., Hoy, W. K., \& Hoy, A. W. (2003). Instructional leadership: A learning-centered guide. Boston, MA: Allyn and Bacon. https://wps.ablongman.com/wps/media/objects/290/297448/Short\%20Cases\%20Guide.pdf

Hung, D. K. M., \& Ponnusamy, P. (2010, September). Instructional Leadership and Schools Effectiveness. In World

Summit on Knowledge Society (pp. 401-406). Springer, Berlin, Heidelberg. https://link.springer.com/chapter/10.1007/978-3-642-16318-0_48

Yaakob, M. F. M., \& Yusof, M. R. Mobile-Mediating In Leadership Practices. https://www.researchgate.net/profile/Mohd_Faiz_Mohd_Yaakob/publication/326753484_Mobile-

Mediating_In_Leadership_Practices/Links/5b625339a6fdccf0b206c825/MOBILE-Mediating-In-Leadership-

Practices.Pdf

Jamelaa B., A. (2012). Instructional Leadership Practice and Principals' Attitudes on Change in Secondary Schools in Pahang. Unpublished PhD thesis, Universiti Kebangsaan Malaysia.

Abdullah, J. B., \& Kassim, J. M. (2011). Instructional leadership and attitude towards organizational change among secondary schools principal in Pahang, Malaysia. Procedia-Social and Behavioral Sciences, 15, 3304-3309. https://doi.org/10.1016/j.sbspro.2011.04.290

Jensen, M. C., \& Murphy, K. J. (1990). Performance pay and top-management incentives. Journal of political economy, 98(2), 225-264. https://doi.org/10.1086/261677

Khan, S., \& Malik, S. (2013). Is teacher leadership a fantasy or reality? A review. Journal of Educational and Instructional Studies in the World, 3(3), 66-72. https://www.researchgate.net/profile/Dr_Sufiana_Khatoon_Malik/publication/264895500_Is_Teacher_Leadership_A_F antasy_Or_Reality_A_Review/Links/5524febb0cf2caf11bfcf00d/IS-Teacher-Leadership-A-Fantasy-Or-Reality-A-

Review.Pdf

Kursunoglu, A., \& Tanriogen, A. (2009). The relationship between teachers' perceptions towards instructional leadership behaviors of their principals and teachers' attitudes towards change. Procedia-Social and Behavioral Sciences, 1(1), 252-258. https://doi.org/10.1016/j.sbspro.2009.01.046

Lewin, K. (1951). Field theory in social science. http://agris.fao.org/agris-search/search.do?recordID=US201300602463 Lee, M., Hallinger, P., \& Walker, A. (2012). A distributed perspective on instructional leadership in International Baccalaureate (IB) schools. Educational Administration Quarterly, 48(4), 664-698. https://doi.org/10.1177/0013161X11436271

Leithwood, K., Day, C., Sammons, P., Harris, A., \& Hopkins, D. (2006). Successful school leadership: What it is and how it influences pupil learning. https://www.researchgate.net/publication/238717790_Successful_School_Leadership_What_It_Is_and_How_It_Influen ces_Pupil_Learning

Lyons, B. J. (2010). Principal instructional leadership behavior as perceived by teachers and principals at New York state recognized and non-recognized middle schools. http://scholarship.shu.edu/cgi/viewcontent.cgi?article=2373\&context=dissertations

Marks, H. M., \& Printy, S. M. (2003). Principal leadership and school performance: An integration of transformational and instructional leadership. Educational administration quarterly, 39(3), $370-397$. https://doi.org/10.1177/0013161X03253412

Mattar, D. (2012). Instructional leadership in Lebanese public schools. Educational management administration \& leadership, 40(4), 509-531. https://doi.org/10.1177/1741143212438222

McEwan, E. K. (2002). Seven steps to effective instructional leadership. Corwin Press.

Mulyasa K. (2012). Principal Management and Leadership. Jakarta: Earth Literacy.

Wahyuni, N. S., Putrawan, I. M., \& Sari, E. The Effect of Instructional Leadership and Persistence on Task Performance. DOI: 10.5281/zenodo.3464986

Printy, S. M., Marks, H. M., \& Bowers, A. J. (2009). Integrated leadership: How principals and teachers share transformational and instructional influence. Journal of School Leadership, 19(5), 504-532. https://doi.org/10.1177/105268460901900501 
Sim, Q. C. (2011). Instructional leadership among principals of secondary schools in Malaysia. Educational Research, 2(12), 1784-1800. https://pdfs.semanticscholar.org/a983/a3979db4adcb7ddc20e0f4a09f43b4227bb4.pdf

Rahimi, M., Y., \& Yusri, M (2015). Virtual instructional contributions to teacher teaching competence. E-Proceeding of the International Conference on Social Scince Research.

Robinson, V. M., Lloyd, C. A., \& Rowe, K. J. (2008). The impact of leadership on student outcomes: An analysis of the differential effects of leadership types. Educational administration quarterly, 44(5), 635-674. https://doi.org/10.1177/0013161X08321509

Sahin, S. (2011). The Relationship between Instructional Leadership Style and School Culture (Izmir Case). Educational Sciences: Theory and Practice, 11(4), 1920-1927. https://files.eric.ed.gov/fulltext/EJ962681.pdf

Sharma, S., Mannan, F., \& Veeriah, J. (2016). Instructional Leadership in Malaysia-The Literature Gaps. Journal Of Global Research In Education And Social Science, 162-167. https://www.academia.edu/27267178/

Santhidran, S., Chandran, V. G. R., \& Borromeo, J. (2013). Enabling organizational change-leadership, commitment to change and the mediating role of change readiness. Journal of business economics and management, 14(2), 348-363. https://doi.org/10.3846/16111699.2011.642083

Scheerens, J. (Ed.). (2012). School leadership effects revisited: Review and meta-analysis of empirical studies. Springer Science \& Business Media. https://link.springer.com/book/10.1007\%2F978-94-007-2768-7

Sim, Q. C. (2011). Instructional leadership among principals of secondary schools in Malaysia. Educational Research, 2(12), 1784-1800. https://www.semanticscholar.org/paper/Instructional-leadership-among-principals-of-inSim/835230ee4b54b7bcdc98d115f605f9decef60bd7

Southworth, G. (2002). Instructional leadership in schools: Reflections and empirical evidence. School Leadership \& Management, 22(1), 73-91. http://dx.doi.org/10.1080/13632430220143042

Spillane, J. P., Halverson, R., \& Diamond, J. B. (2001). Investigating school leadership practice: A distributed perspective. Educational researcher, 30(3), 23-28.10.3102/0013189X030003023.

Sukarmin (2010) The Relationship Behavior of Teacher-led Teaching with School Efficiency, Organizational Commitment, Effectiveness and Teacher Satisfaction. PhD. thesis, University of Northern Malaysia https://core.ac.uk/download/pdf/82262288.pdf

Suseela, M. and K.H. Sim, 2010. Teacher perspectives of school-based assessment in a secondary school in Kuala Lumpur. Procedia-Social and Behavioral Sciences, 9: 1170-1176.

Urick, A., \& Bowers, A. J. (2014). The impact of principal perception on student academic climate and achievement in high school: how does it measure up?. Journal of School Leadership, 24(2), 386414.https://doi.org/10.1177/105268461402400207

Wan R., W. I. (2011). Correlation of Intermediate Leadership Teaching Practice with School Climate, Teacher Work Attitude and Organizational Commitment in Secondary Schools

Weber, Y. (1996). Corporate cultural fit and performance in mergers and acquisitions. Human relations, 49(9), 11811202. https://doi.org/10.1177/001872679604900903

Yusri M., \& Aziz I., A. (2014). Leadership models of teaching leadership and competency teacher teaching. Asia Pacific Curriculum \& Travel Journal, (1), 11-25.

Aziz, Z., \& Baba, S. (2011). Instructional leadership enhanced creativity in smart classroom activities. Procedia-Social and Behavioral Sciences, 15, 1566-1572. https://doi.org/10.1016/j.sbspro.2011.03.332 